\title{
Evaluation Process Associated with Multiple Intelligences in High School Students of the Ecuadorian Educational System
}

\author{
Liliana Magdalena Alcívar Rodríguez \\ Pontificia Universidad Católica del Ecuador Manabí, Portoviejo, Ecuador \\ Corresponding author email: lalcivar9842@ pucem.edu.ec \\ Karina Eliana Castro Intriago \\ Pontificia Universidad Católica del Ecuador Manabí, Portoviejo, Ecuador \\ Email: kcastro9281@pucem.edu.ec \\ Luis Alfredo Tubay Cevallos \\ Pontificia Universidad Católica del Ecuador Manabí, Portoviejo, Ecuador \\ Email: ltubay6405@pucem.edu.ec \\ Lubis Carmita Zambrano Montes \\ Pontificia Universidad Católica del Ecuador Manabí, Portoviejo, Ecuador \\ Email: lzambrano1371@pucem.edu.ec
}

\begin{abstract}
Formative assessment is ideal for improving teaching and learning processes. However, little is practiced systematically and a traditional approach still persists in many educational institutions that value the product rather than the process. The objective of this study is to determine the evaluative process associated with multiple intelligences in high school students from an Educational Unit in the city of Manta. Methodologically, this research project is of a mixed type with a qualitative-quantitative approach since it obtains real data that evaluates the results. To collect the information, information from primary sources will be used and will be carried out through a survey via Google to teachers and secondary information will be taken from accredited sources of virtual libraries, indexed magazines, and other academic Google publications. The results will be processed using statistical methods that will allow their analysis and interpretation. As a result of it, a set of formative evaluation activities underlying the pedagogical practice of the teacher was obtained, assessing the general process of formative evaluation of learning included in the teaching-learning processes. The process is useful for conducting a conscious and systematic formative assessment.
\end{abstract}

Keywords---evaluation instruments, evaluative process, learning assessment, multiple intelligences.

\section{Introduction}

Evaluating human intelligence and cognitive abilities is one of the controversial aspects in the psychoeducational field, especially if the evaluation does not consider that intelligence is not a whole, on the contrary, it is dissected into several multiple intelligences. Aliaga et al. (2012) in allusion to the word intelligence mention that it is an old term that only appeared in the psychological bibliography in the early years of the 20th century, since before it predominated the doctrine of the powers referring in terms of judgment, reasoning or intellect.

López et al. (2008) point out that there is considerable disagreement regarding the concept of "intelligence", as a consequence a diversity of theories have been developed on the different aspects of intelligent execution. One of these theories is Howard Gardner's Multiple Intelligences, which sees intelligence as the ability to solve problems and to create cultural products. From this point of view, intelligence is a concept fully related to creativity. Once the 
Theory of Multiple Intelligences has been formulated and validated, Gardner and his group of collaborators believe it is convenient to design a procedural mechanism that allows the intelligences that are generated in educational spaces to be evaluated in a contextualized and ecological way.

The abilities of the students are observable taking into account the cognitive behavior they have in each area of human knowledge, for which a series of activities related to the eight intelligences and how they are stimulated are used. This is done using psychometric tests that only give value to some intellectual dimensions or cognitive processes such as: verbal comprehension, concept formation, concrete, abstract, numerical and calculation reasoning skills, logical thinking, use of memory, ability to classify and generalize, common sense, moral and ethical judgment, ignoring others such as: spatial location, tone, rhythm and musical timbre, abilities to accurately perceive the visual world, control of own body movements and the ability to handle objects with skill, access to the sentimental life itself, the ability to notice and establish distinctions between other individuals in an interpersonal way and in particular between their moods, temperament, motivations and intrapersonal intentions.

Experiential experiences inside and outside the classroom also represent another factor to take into account in the observation. Students who little or nothing interact with concrete material such as coins and bills, will be far from developing logic skills and rapid and basic calculation, they probably do not show strong points in the numerical area, it is convenient to introduce them in that domain or area of human knowledge. The teacher has didactic guides that include skills for each of the intelligences, while the students work independently in a learning center (Prieto et al., 2001; Akbari \& Hosseini, 2008; Al-Kalbani \& Al-Wahaibi, 2015).

Faced with this reality, the research will determine the evaluative process associated with multiple intelligences in high school students of an educational unit in the city of Manta, it shows that correct evaluative practice, the appropriate use of instruments, the analysis of abilities Varied intellectuals and measurable knowledge activities, carried out by the teachers who teach classes, make the development of multiple intelligences possible. In contrast, there is the lack of knowledge of evaluative processes linked to the quantification of multiple intelligences, which prevents the assessment of the individual's real capacities, limiting traditional academic practices with predictable results, where their analysis does not show a correct development of human intelligence.

Over the years, the learning evaluation process has taken a leading role, it is the starting point as the main topic in conferences. debates or workshops on pedagogy are given a high degree of importance due to its significance in the education of the student. This was not always the case, at the beginning the learning theories and therefore their evaluation were dominated by psychologists where their personal interests were clearly identified when promoting them, causing the teacher to use controlling and rigorous practices, leaving a repetitive process and rote. Over the years you are practices have evolved, the art of teaching and evaluating received an indispensable priority since the student is allowed to partake in different fields, the assessed be motivated to practice critical reflective thinking revealing their full cognitive development.

When talking about evaluative processes in learning, it must be identified how the sequential system results after carrying out the transmission of content to the student, it is highly relevant when the teacher begins when giving his master class, applies the correct techniques and methodologies to reach the student with significant learning and complying with the evaluation cycle (Walter et al., 2008; Kurniawan, 2019; Shearer \& Karanian, 2017). Learning implies changes, it must last over time, this occurs based on experience, generating inferential learning, giving premises of what the student acquires, expresses or performs. The observation of the product or result as such involves determining the level of knowledge achieved in a specific subject, the content measurement can be through structured basic tests, obtaining clear evidence of the domain of the subject, but skills can also be evaluated and skills achieved in their self-control, values or motivation, among others, which generates changes in the way of life and behavior of the learner (Schunk, 2012).

Achieving achievements and planned skills must have a sequential thread, since they are a reflective practice of the teacher in charge, since the student receives content, interprets it, transforms it and makes it his own. A qualitative evaluative process is identified, which is transformed into quantitative by granting it a complete methodology through the evaluation instruments, specifying that the performance of the educator favors the complete holistic development of the student, the mastery of the subject is fundamental when evaluating systematically through the established parameters (Quirós \& Jiménez, 2013).

The teacher must compare the starting point with the arrival point in the teaching-learning process, measure the structure, process and product of education. Among the most common applied methods to carry out this process is the observation of behavior patterns that demonstrate their learning, there are also written or oral exams, as well as learning practices based on problems and/or challenges among others, where you can clearly assess the degree of understanding and mastery of the topic covered (Schunk, 2012; Sulaiman et al., 2010; Visser et al., 2006; Mejía et al., 2019). 
The evaluation process answers the main questions: Why and for what to evaluate? (González, 2001). These questions being the main ones to take into account in the learning evaluation since it allows to measure and regulate the degree of knowledge, adapt the techniques necessary for the transmission of content, ensuring that the assimilation is precise at the time of being evaluated. Lto teachinglearning as such, follows the patterns thatgenerate interest in the learner is to adapt the techniques applied and that the evaluation process achieves unwrap all the talents of the student, focused on different ways of learning (Armas, 2019).

Evaluation is part of teaching-learning and should be considered as the fundamental activity in the educational process, it is scientific, systematic, comprehensive, continuous, permanent, participatory, flexible and formative. The training of the student must be complete and effective based on finding the development of their competences, leaving as evidence to the teacher that satisfaction of the duty fulfilled with the transmission of content, the theory of multiple intelligences allows to know the profile of each one of them, allowing intervene with adequate and consistent instruction in their way of inference learning, being an optimal, precise and useful result when evaluating acquired learning (Meléndez \& Escobar, 2020).

It is normal for the teacher to forget to adapt the evaluation to the way of teaching, a fact that does not go unnoticed by the students, representing a concern at the time of the evaluation throughout their learning, the exams do not demonstrate the total knowledge of the student, the teacher evaluation must Being formative, it must be carried out according to what is stipulated in the education curriculum, according to the level of the students. It assumes two types of functions, one of a pedagogical nature and the other of a social nature, distributed throughout the teaching-learning process (Alfagame \& Miralles, 2009).

The pedagogical evaluation serves the student in their learning, verifies what they have learned in the teaching process (Martel, 2004). The formative evaluation is given with the help of previously defined criteria, in attention to the pedagogical objectives and of formative action. This assessment can be carried out at different times, is practiced during the course of learning and aims to teach the student in the most complete and accurate way about the distance that separates him from the objective and the difficulties he may face. It serves to build knowledge using tests and reports. Summative evaluation is carried out at the end of the learning period and is intended to verify whether the objectives were achieved by the students. It is the sum of the results and all the tests and means of evaluation, it is the one that accredits, promotes and decides.

Self-regulation of learning makes explicit reference to the participation of the students in the didactic objectives, the reconstruction of their experiences, the realization of proposals where autonomous, reflective and critical thinking is developed. It aims to get students to build their own learning system and progressively improve it by forming meaningful learning (García et al., 2007).

Currently, there are tools other than the traditional exam to evaluate students, such as rubrics, checklists, the portfolio of evidence, among others. Similarly, it is necessary to point out that there are activities or products that can be used for the same purpose, such as: models, plays or audios; which, if well defined criteria are established, can be useful to evaluate learning.

The evaluation is necessary in the teaching-learning process because through this it is possible to detect difficulties in the students, it allows the teacher to discover their strengths and weaknesses and help them to solve the problems. The evaluation process allows students to have confidence in themselves, to acquire responsibility and provides them with the necessary motivation to apply what they have learned outside of the classroom (Andreu, 2009).

Currently there are several evaluation methods that facilitate a good result of the teaching-learning process, group work favors the evaluation process by improving their abilities to solve problems, their capacity for reflection, critical thinking and learning for life, without losing sight of since it is an essential component of formative assessment. Self-evaluation and co-evaluation are part of the teacher's methodology to evaluate the knowledge generated in their class, this should focus on recognizing and generating the meaningful learning that will contribute to the development of the student's entire life and what it will lead to practical life (Fernández, 2017).

The evaluation is closely related to the style of work developed by the teacher, that is, the way in which a student interacts with specific materials, the learning environment or environment of an intelligence or area of knowledge. To correctly evaluate multiple intelligences, it is necessary that the evaluation instruments and thematic axes are in accordance with the capacities or aptitudes of the students, who show interest in some intelligence, but who also feel frustrated when they are evaluated in areas that they do not master and simply they are not to the liking. It is important that the teacher analyze the difficulty of a student with a certain task, because it helps him to individualize the instruction and find optimal results in the resolution. 


\section{Materials and Methods}

In the research, qualitative quantitative approaches were combined, statistics were used to interpret and verify the variables, as well as the deductive, inductive, and probative method in order to obtain data and test the variables. With the use of the qualitative and quantitative method, an analysis was constructed that determined the degree of knowledge applied by teachers in the evaluative process, which is associated with multiple intelligences, and thus a conscious and systematic formative evaluation was carried out. These methods use a rigorous and careful process to obtain concrete and truthful results, since by their application both are executed equally (Hernández et al., 2014). The population that was investigated was 43 teachers from the high school section of an Educational Unit of the city of Manta, it was investigated with $100 \%$ of the population. An online survey of the digital tool of forms belonging to Google was applied and the secondary information was taken from accredited sources of virtual libraries, indexed magazines, and other academic Google publications.

\section{Results and Discussions}

Considering that the learning process goes through three moments: acquisition or construction, review and transfer of knowledge, feedback is the time to detect the learning actually achieved on the basis of the transfer of knowledge that the student makes to other areas and/or other contexts. Among other appropriate dynamics for this moment, you can ask questions to the section about the experience of what was lived in the class, ask the students to write a synthesis and share it, read the conclusions of the work carried out in the group, ask them to think in the possible applications of what has been learned in other subjects, areas, or in their daily life. In addition, it is important to take advantage of the moment to teach them to give feedback to each other (Pasek \& Mejía, 2017).

Technology offers a variety of tools or applications available to teachers, as well as other options to appropriately assess student learning. The evaluation instruments are the means that the teacher will be able to register and obtain the necessary information to verify the achievements or difficulties in their students, these can be used according to their needs. Figure 1 shows the types of evaluation instruments and examples of each of them.

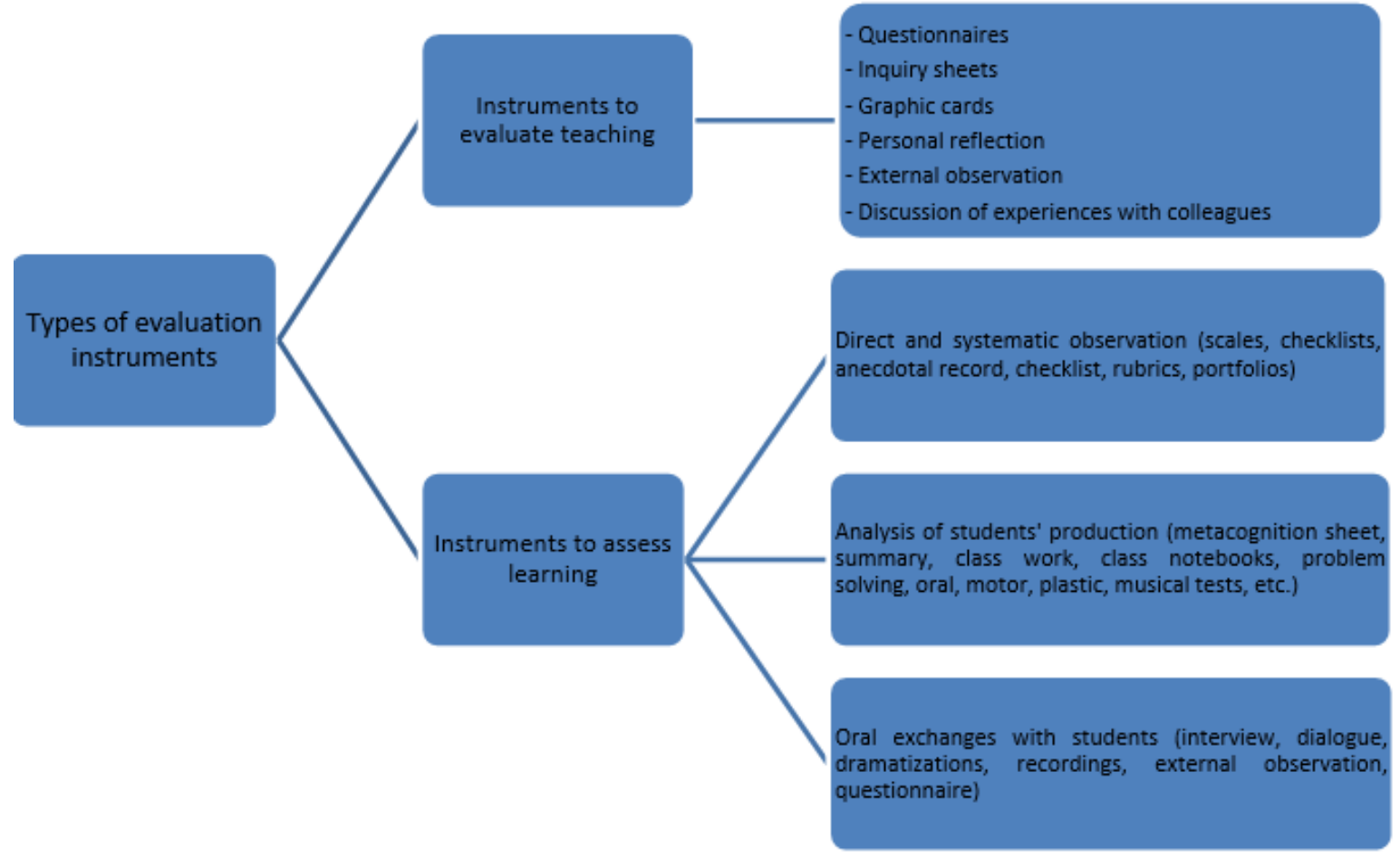

Figure 1. Types of evaluation instruments 
The function of evaluation in the teaching-learning process carried out by teachers was analyzed to measure the knowledge that students have; the results are shown in Table 1.

Table 1

Evaluative function in the teaching-learning process

\begin{tabular}{ccc}
\hline Alternatives & Frequency & Percentage (\%) \\
\hline $\begin{array}{c}\text { The structure, process and product of } \\
\text { education are evidenced. }\end{array}$ & 33 & 76.7 \\
$\begin{array}{c}\text { Knowledge is measured only quantitatively. } \\
\text { nof }\end{array}$ & 10 & 23.3 \\
\hline
\end{tabular}

It was detected that $76.7 \%$ of teachers state that the evaluative function is fundamental in teaching-learning, allowing the structure, process and product of education to be correctly demonstrated, in addition $23.3 \%$ consider that They only serve to quantitatively measure the results obtained, without taking into account that when evaluating it is considered from how the student enters to the exit profile of the student. The evaluation retroactively influences the way of learning and teaching, it is necessary to understand how the student understands what is being asked of him, how he reinterprets his knowledge to adjust it to the demands made and how he generates the answer, to build better indexes of development of expertise and not simple memorizations or inert applications of knowledge (Castañeda, 2004). It was investigated how evaluation contributes to the development of multiple intelligences to the different areas of knowledge, the results are shown in Figure 2.

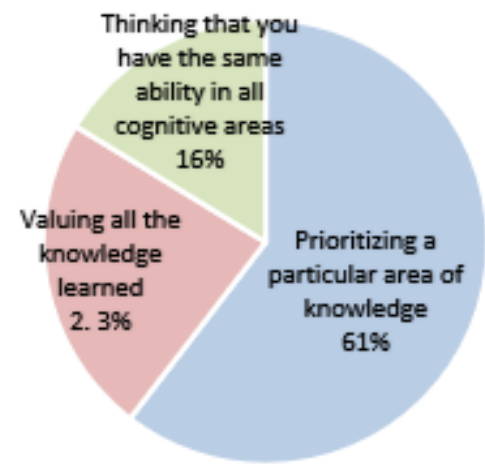

Figure 2. Evaluation oriented to multiple intelligences

It was found that $61 \%$ of teachers value that evaluation contributes regarding the knowledge learned, only $16 \%$ believe that they have the same capacity in all cognitive areas, showing that evaluation is necessary for the development of multiple intelligences in all the knowledge learned. The educational system and teaching evaluation practice is not neutral, it does not pay the same attention to all learning styles, nor does it value all intelligences or abilities equally. The schedules of the subjects that students receive are not equitable so they do not spend the same time developing body-kinesthetic intelligence and linguistic intelligence, to cite two examples (Luca, 2004). Selfregulation reinforces the content of the evaluation, being able to verify the participation of the students in the didactic objectives, for which the participation of the students in the process was investigated, Table 2 shows the results reported by the teachers. 
Table 2

Student participation in teaching objectives

\begin{tabular}{ccc}
\hline Alternatives & Frequency & Percentage (\%) \\
\hline Always & 18 & 41.9 \\
Almost always & 18 & 41.9 \\
Sometimes & 6 & 14.0 \\
Never & 1 & 2.3 \\
\hline
\end{tabular}

It was shown that teachers apply the self-regulation process to measure learning of the students in the fulfillment of the didactic objectives, as it is observed in the table always or almost always the majority of all the teachers apply the methodology. Self-regulation strategies in learning optimize the use of cognitive operations carried out during the learning of different subjects, as well as motivational-affective strategies in students (De la Fuente and Justicia, 2003). The investigated teachers consider that multiple intelligences contribute to the evaluation process with significant learning in the teaching-learning process since they all recognize that this methodology enriches the students' knowledge to face the evaluation.

Regardless of the controversy of considering intelligences, capacities or strengths to those faculties developed in people, it is useful for teachers to diagnose them in students, it allows to understand and outline the appropriate activities to obtain the maximum use (Luca, 2004). The multiple intelligences that each student possesses have a significant impact on grades, demonstrated in the results obtained where it is considered that some students take advantage of cognitive development in some areas of knowledge, prevailing as this methodology interferes with the student. Each individual has a unique profile of combination of intelligences, different windows with which to learn and demonstrate what they have learned, enhancing their intellect, which is evidenced in their academic results (Sánchez, 2015).

\section{Conclusion}

The evaluative processes are clearly linked to the multiple intelligences of the teaching-learning of the student of the high school section of an Educational Unit of the city of Manta, being verified in the systematic analysis of the data provided, starting from important aspects that give validity to the present investigation carried out, where the teacher assesses the methodology in a clear and suitable way, using known techniques. The evaluative processes are fundamental in teaching-learning because they show the structure, process and product of the evaluation that is associated with multiple intelligences that allow evaluating the cognitive development of the student, evaluating all the knowledge learned, determining a heterogeneous and significant learning.

\section{Acknowledgments}

We are grateful for the tutoring of Dra María Rodríguez Gámez, professor of the Job Design module of degree I, at the Pontificia Universidad Católica del Ecuador.

\section{References}

Akbari, R., \& Hosseini, K. (2008). Multiple intelligences and language learning strategies: Investigating possible relations. System, 36(2), 141-155. https://doi.org/10.1016/j.system.2007.09.008

Alfagame, M., Miralles, P. (2009). Assessment instruments to focus our teaching on student learning. Iber: Didactics of Social Sciences, Geography and History, 60, 2-5. Retrieved from https://scholar.google.es/scholar?hl=es\&as_sdt=0\%2C5\&q=INTRUMENTOS+DE+EVALUACI\%C3\%93N+EN + EL+LEARNING\&btnG=

Aliaga, J., Ponce C., Bulnes M., Elizalde, R., Montgomery, W., Gutiérrez, V., Delgado E., Perea, J., and Torchiani, R. (2012). Multiple intelligences: assessment and relationship with performance in mathematics in fifth-year high 
school students from lima metropolitana. IIP Magazine, 15(2), 163-202. Retrieved from http://pepsic.bvsalud.org/pdf/ripsi/v15n2/a12.pdf

Al-Kalbani, M. S., \& Al-Wahaibi, S. S. (2015). Testing the multiple intelligences theory in Oman. Procedia-Social and Behavioral Sciences, 190, 575-581. https://doi.org/10.1016/j.sbspro.2015.10.001

Andreu, M. (2009). Students as evaluators in the teaching-learning process. Ibero-American Journal of Education. 50(1), 2-3. Recovered from https://dialnet.unirioja.es/servlet/articulo?codigo=3019063

Armas, M. (2019). Make learning flow. International Journal of Developmental and Educational Psychology, 2(1), 299-309. Retrieved from https://www.redalyc.org/articulo.oa?id=349860126029

Castañeda, S. (2004). Evaluating and fostering cognitive development and complex learning. Psychology from the Caribbean, (13), 109-143. Recovered https://www.redalyc.org/pdf/213/21301307.pdf

De la Fuente, J., and Justice,J.(2003). Regulation of teaching for self-regulation of learning at the University. Open classroom, (82), 161-172. Retrieved from https://dialnet.unirioja.es/servlet/articulo?Codigo=1012077

Fernández, S. (2017). Evaluation and learning. Journal of Spanish Foreign Language Didactics. 24. Retrieved from https://www.redalyc.org/jatsRepo/921/92153187003/html/index.html

García, A., Ramos, G., Díaz, M., and Olvera, A. (2007). Evaluation instruments. Revista Mexicana de Anestesiología, 30(3), 158-164. Retrieved from https://n9.cl/6npd8

González, M. (2001). The evaluation of learning: Trends and critical reflection. Rev Cubana Educ Med Super. 15 (1), 85 - 96. Retrieved from http://scielo.sld.cu/pdf/ems/v15n1/ems10101.pdf

Hernández, R., Fernández, C. and Baptista, P. (2014). Investigation methodology. Retrieved from http://www.intercambiosvirtuales.org/libros-manuales/roberto-hernandez-sampieri-metodologia-de-lainvestigacion-6a-edicion\#more-78680

Kurniawan, L. S. (2019). Emotional Intelligence and Marital Decision: Study on Bali Family Center Clinic, Denpasar-Bali. International Journal of Health Sciences, 3(2), 11-20.

López, D., Henao, L., and Suárez, O. (2008). Evaluation of multiple intelligences in boys and girls with low scores in IQ. Investigaciones Andina, 10 (17), 27-44. Retrieved from https://www.redalyc.org/pdf/2390/239016505003.pdf

Luca, S. (2004). The teacher and multiple intelligences. Ibero-American Journal of Education, 34 (1). Retrieved from https://rieoei.org/RIE/article/view/2884

Martel, A. (2014). Social and individual evaluation in the era of distance education in globalization. Electronic journal of educational research 6(1), 5. Retrieved from http://www.scielo.org.mx/scielo.php?script=sci_arttext\&pid=S1607-40412004000100010

Mejía, R. O. G., Mendoza, M. F. A., Zambrano, Y. A. Z., Loor, B. M. V., \& Delgado, G. M. P. (2019). Evaluation Process of Multiple Intelligence in Collegiate. International Journal of Social Sciences and Humanities, 4(1), 117-127.

Meléndez, J. and Escobar, C. (2020). The theory of multiple intelligences and its implication in the teaching of history. Journal of Research in Didactics of Social Sciences, 4(6), 43-60. Recovered from https://dialnet.unirioja.es/servlet/articulo?codigo $=7394288$

Pasek, E., Mejía, M. (2017). General process for formative assessment of learning. Journal IberoAmerican -of Educational Evaluation. 10(1), 190. Recovered from https://dialnet.unirioja.es/servlet/articulo?codigo=5913181

Prieto, M., Ferrándiz, C., and Ballester, P. (2001). Evaluation of cognitive competence from the theory of multiple intelligences. Enseñanza \& Teaching:Journal Interuniversity of Didactics, 19, 91-111. Recovered from https://dialnet.unirioja.es/servlet/articulo?codigo $=272195$

Quirós, E. and Jiménez, X. (2013). The attitude towards teaching, the integral formation in secondary education and its life project: A vision from the students of schools in rural areas. Educare Electronic Magazine, 17 (2), 91-109. Retrieved from https://www.redalyc.org/articulo.oa?id=1941/194127506007

Sánchez, N. (2015). Multiple intelligences in the classroom. Towards a new model of school and learning. Revista Padres y Maestros / Journal of Parents and Teachers, (361), 49-54. Retrieved from https://revistas.comillas.edu/index.php/padresymaestros/article/view/5342/5141

Schunk, D. (2012). Learning theories. An educational perspective. Recovered from https://www.freelibros.me/libros/teorias-del-aprendizaje-una-perspectiva-educativa-6ta-edicion-dale-h-schunk

Shearer, C. B., \& Karanian, J. M. (2017). The neuroscience of intelligence: Empirical support for the theory of multiple intelligences?. Trends in neuroscience and education, 6, 211-223. https://doi.org/10.1016/j.tine.2017.02.002

Sulaiman, T., Abdurahman, A. R., \& Rahim, S. S. A. (2010). Teaching strategies based on multiple intelligences theory among science and mathematics secondary school teachers. Procedia-Social and Behavioral Sciences, 8 , 512-518. https://doi.org/10.1016/j.sbspro.2010.12.070 
Visser, B. A., Ashton, M. C., \& Vernon, P. A. (2006). g and the measurement of Multiple Intelligences: A response to Gardner. Intelligence, 34(5), 507-510. https://doi.org/10.1016/j.intell.2006.02.004

Walter, R., Gómez, Y., and Herazo, T., and Pérez, E. (2008). The teacher's discourse inprocesses evaluative and its impact on learning. Journal of the Institute of Higher Studies in Education, 9, 12-27. Recovered from https://dialnet.unirioja.es/servlet/articulo?codigo $=2898446$. 